\title{
サンドドレーンによる $K_{0}$-圧密理論の研究 \\ A STUDY OF LATERALLY CONFINED CONSOLIDATION \\ OF CLAY BY DRAIN WELLS
}

\author{
中 野 坦* \\ By Hiroshi Nakano
}

\section{1.まえがき}

自然地盤中で， $K_{0}$-状態のもとに圧密された粘土に， 構造物等による増加圧力が加えられるとき, この増加圧 の大部分が過剩間げき水圧となって平衡される。過剩間 げき水圧は一時的な支持能力をもつに止まり, 圧密の進 行とともに, 永久的支持能力をもつ粒子間応力へと置換 していく。この際, 付帯条件として, 間げき水の離脱に 伴う体積の減少といらことが付随する。

間げき水圧は等方性応力であるから，その減少に伴う 体積変化は当然の帰結として, 等方的であり, 側方収縮 をもたらす。

ここで, 構造物の沈下の形態を考察する。

図一1 に示すように, 載 荷に伴って, 構造物下の土 柱を形成する土塊は, 側方 拘束圧のより小さい土柱上 部において, せん断変形に よる側方膨張, すなわち, 非排水状態での側方流動に よって瞬時沈下といわれる 沈下を起こす。

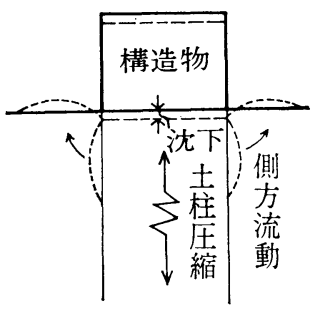

図-1
これとは別に，過剩間げき水圧によって生ずる間げき 水の離脱から, 圧密沈下を起こすのであるが, この際, いったん側方に押し出された土塊が逆に土柱下に押し戻 されることはないと考えられる。なぜなら，土柱の外側 の低応力部から高応力部である土柱へ土塊が流動する要 因はないからである。

いま, 上記のように, 圧密沈下中の側方流動が起こら ないと仮定し得るならば，圧密によって生ずる側方収縮 は側方拘束圧力の緩和をもたらし, 圧密変形とせん断変 形による沈下が混在する。また，もし側方流動が皆無と

* 正会員 近畿大学助教授 理工学部土木工学科
するならば，一般に， $K_{0}$-圧密といわれる側方変形が零 状態での圧密が現出する。

しかし, 現段階では, 圧密沈下中の側方流動の有無が 明確にされていないから, 確定的なことはいえないが, 自然地盤中での圧密沈下が，どちらかというと $K_{0}$-状 態に近い条件で起こると考える方がより合理的なように 思われる。

そこで, 前報1)に引き続き, $K_{0}$-状態での圧密に適応 するようサンドドレーン圧密理論の修正を試み, 室内試 験において検照を行なった。

\section{2. 従来のサンドドレーンに関する理論}

\section{（1）圧密速度に関する理論}

土が等方等質であるとして，三次元圧密に関する微分 方程式が

$$
\begin{aligned}
& \frac{k}{r_{w}} \nabla^{2} u=\frac{\partial \varepsilon}{\partial t} \\
& \text { ここに } \quad k: \text { 土の透水係数 } \\
& r_{w} \text { : 水の笊位体積重量 } \\
& u: \text { 閒げき水圧 } \\
& \varepsilon: \text { 体積ひずみ }
\end{aligned}
$$

であり, 間げき水圧 $u$ と体積ひずみ $\varepsilon$ との間に

$$
\begin{aligned}
\varepsilon=\frac{3(1-2 v)}{E} u \cdots \cdots . . . \\
\text { ここに } \quad \begin{array}{r}
v: \text { ポアソン比 } \\
E: \text { ヤング係数 }
\end{array}
\end{aligned}
$$

なる関係があることから Rendulic ${ }^{2)}$ は

$$
C_{v} \nabla^{2} u=\frac{\partial u}{\partial t}
$$

とし,また, 三笠 ${ }^{31}$ は

$$
C_{v} \Delta^{2} \varepsilon=\frac{\partial \varepsilon}{\partial t}
$$


ここに, $C_{v}=\frac{k}{r_{w}} \cdot \frac{3(1-2 v)}{E}$

であるとした。

サンドドレーンのように, 非等方性, 等質の軸対称流 れを有する圧密の場合, 式 (3.a) は

$$
C_{v v} \frac{\partial^{2} u}{\partial z^{2}}+C_{v h}\left(\frac{\partial^{2} u}{\partial r^{2}}+\frac{1}{r} \frac{\partial u}{\partial r}\right)=\frac{\partial u}{\partial t}
$$

なる Terzaghi-Rendulic 式が得られる。

Carrillo4) は

$$
u=u_{1} u_{2}
$$

と置き,

$$
\begin{aligned}
& \frac{\partial u_{1}}{\partial t}=C_{v} \frac{\partial^{2} u}{\partial z^{2}} \\
& \frac{\partial u_{2}}{\partial t}=C_{v h}\left(\frac{\partial^{2} u_{2}}{\partial r^{2}}+\frac{1}{r} \frac{\partial u_{2}}{\partial r}\right)
\end{aligned}
$$

として， $u_{1}, u_{2}$ を式 (6), (7) の解とすると

$$
\begin{aligned}
u_{2}\left(C_{v v} \frac{\partial^{2} u_{1}}{\partial z^{2}}\right. & \left.-\frac{\partial u_{1}}{\partial t}\right) \\
& +u_{1}\left[C_{v h}\left(\frac{\partial^{2} u_{2}}{\partial r^{2}}+\frac{1}{r} \frac{\partial u_{2}}{\partial r}\right)\right. \\
& \left.-\frac{\partial u_{2}}{\partial t}\right]=0 \quad \cdots \cdots \cdots \cdots \cdots \cdots \cdots
\end{aligned}
$$

となることを見いだした。

すなわち, 式 (4) の解は式 (6), (7) を独立に解いて $u_{1}, u_{2}$ を求め, 式 (5) によって得られることがわかる。 したがって, 合成流れによる圧密度 $U$ は式 (5)によっ $\tau$

$$
(1-U)=\left(1-U_{v}\right)\left(1-U_{h}\right)
$$

ここに $U_{v}=1-\frac{\bar{u}_{1}}{u_{0}}=$ 鉛直流れによる圧密度

$$
\begin{aligned}
& U_{h}=1-\frac{\bar{u}_{2}}{u_{0}}=\text { 水平流れによる圧密度 } \\
& \bar{u}=\text { 平均間げき水圧 }
\end{aligned}
$$

となる。

実際に, サンドドレーンが現場で使用されるとき, 三 角形, あるいは正方形配置で打設されるから, サンドド レーンの 1 本当りの排水領域を定めてやらねばならな い。水平方向の排水領域は正方形配列の場合は正方形, 三角形配列の場合は正六角形となるが，上記のように圧 密基本式が円筒座標で表わされているから，それぞれの 排水領域と同面積を有する円で近似することを Barron $^{5)}$ は提案した。この円を有効円といい, 有効円の半径 $r_{e}$, サンドドレーンの半径 $r_{w}$ で表わすことにする。

Rendulic, および Carrillo の理論に基づいて, Barron は式 (7) を

$$
\left.\begin{array}{lll}
0<z<h & r=r_{w} & u=0 \\
0<z<h & r=r_{e} & \partial u / \partial r=0
\end{array}\right\}
$$

なる境界条件のもとに解いた。

この際, 鉛直方向の変形が自由（free strain）の場合
と，剛性基礎下に使われるサンドドレーンのように，鉛 直方向の変形が均等である (equal strain) の場合とに ついて求めた。 equal strain についての解を示すと,

$$
\begin{gathered}
u=\frac{\bar{u}}{\lambda d_{e}{ }^{2}}\left[r_{e}{ }^{2} \log _{e}\left(\frac{r}{r_{w}}\right)-\left(\frac{r-r_{w}}{2}\right)\right] \cdots \\
こ こ に, \quad \bar{u}=\bar{u}_{0} \exp \left(-\frac{8 T_{v}}{\lambda}\right), \quad T_{h}=\frac{C_{h} t}{4} \frac{r_{e}{ }^{2}}{4} \\
\lambda=\frac{n^{2}}{n^{2}-1} \log _{e} n-\left(\frac{3 n^{2}-1}{4 n^{2}}\right), n=r_{e} / r_{u}
\end{gathered}
$$

である。free strain と, equal strain との相違は圧密 の初期において free strain の方が若干速く起こること がわかっている。

矢内・水野奋らは, ベッセル関数を用いて free strain の場合について解析し

$$
\begin{aligned}
& u=2 u_{0} \sum_{\xi} A_{\xi}\left[J_{0}\left(\frac{\xi}{r_{w}} r\right)-\frac{J_{1}(n \xi)}{Y_{1}(n \xi)} Y_{0}\left(\frac{\xi}{r_{w}} r\right)\right] \\
& \cdot \exp \left(-4 n^{2} \xi^{2} J\right) \\
& \text { ここに, } A_{\xi}=\frac{V_{1}(\xi)}{\xi\left[V_{1}{ }^{2}(\xi)-n^{2} V_{0}^{2}(n \xi)\right]} \\
& V_{0}(n \xi)=J_{0}(n \xi)-\frac{J_{1}(n \xi)}{Y_{1}(n \xi)} Y_{0}(n \xi) \\
& V_{1}(\xi)=J_{1}(\xi)-\frac{J_{1}(n \xi)}{Y_{1}(n \xi)} Y_{1}(\xi)
\end{aligned}
$$

である。

また，Leeuw ${ }^{7)}$ はひずみに関する基本式 (3. b ) にお いて，円筒座標における応力ーひずみの関係

$$
\begin{aligned}
& \sigma_{r}=2 G\left\{\frac{\partial \rho}{\partial r}+\frac{v}{1-2 v} \varepsilon\right\} \\
& \sigma_{\theta}=2 G\left\{\frac{\rho}{r}+\frac{v}{1-2 v} \varepsilon\right\} \\
& \sigma_{z}=2 G\left\{\frac{\partial \xi}{\partial z}+\frac{v}{1-2 v} \varepsilon\right\}
\end{aligned}
$$

ここに, $\rho:$ 放射方向の変位

$$
\xi: \text { 軸方向の変位 }
$$

$$
\varepsilon: \text { 体積ひずみ }
$$

によって

$$
\left.\begin{array}{lcc}
0<z<h & r=r_{e} & \rho=0 \\
0<z<h & r=r_{w} & \rho=0 \\
z=h & r_{w}<r<r_{e} & \sigma_{z}=p \\
0<z<h & r=r_{w} & u=0 \\
0<z<h & r=r_{e} & \partial u / \partial r=0
\end{array}\right\}
$$

なる境界条件で解き, 結果として free strain の場合の 解と同じものを得ている。

上記のこれらの理論は，いずれも間げき水圧と体積ひ ずみとの関係が式 (2) に従うものとしているから, 圧密 中に水平方向の変形が生ずることになり, 実際の挙動と は合致しない。 


\section{（2）沈下量の算定に関する理論}

沈下量の算定法は, 最初, 全沈下量が側方拘束状態で の鉛直ひずみ，すなわち，一方向ひずみからもたらされ るとして

$$
\left.\begin{array}{l}
S_{T F}=S_{\text {oed. }} \\
S_{T t}=U S_{\text {oed. }}
\end{array}\right\}
$$

ここに, $S_{T F}:$ 最終的に起こる沈下量

$S_{\text {oed. }}$ : 側方拘束状態での最終沈下量

$S_{T t}:$ 任意時間後に生ずる沈下量

$U:$ 圧密度

によった。これは，今日でも比較的薄い粘土層が幅広い 載荷面積にわたって載荷され, 圧密を受ける場合という 条件のもとで適用される。

上記条件の適用外では，側方膨張による鉛直ひずみの 増加が付随し，これが沈下量に扗よぼす影響を無視でき ないものにする。

最初に三次元ひずみの問題として沈下量を算定するこ そを提案したのは Biot であった。

$\mathrm{Biot}^{8)}$ の理論はごく限られた問題にしか解が得られて いないこと, せん断変形による瞬時沈下を考えていない こと等によって実用されることは少ない。

Skempton-Bjerrum ${ }^{9}$ ) は沈下がせん断変形による瞬時 沈下 $S_{i}$ と圧密沈下による $S_{c}$ との和

$$
S_{T F}=S_{i}+S_{C F}
$$

として, フーチングの中央における沈下量を算定する方 法を提案した。ここに, 瞬時沈下は非排水状態でのせん 断変形による沈下で

$$
S_{i}=\frac{3}{4} \frac{q B I_{\rho}}{E}
$$

ここに, $q$ : フーチングに載荷された等分布荷重

$B:$ フーチングの幅

$I_{\rho}:$ フーチングの形状に関する係数

$E:$ 土のヤング係数

である。また， $S_{c}$ は三次元ひずみによる圧密沈下量で 一次元圧密による沈下量 $S_{\text {ced. }}$. に補正係数 $\mu$ を乗じて 得られる。

$$
\begin{gathered}
S_{c}=\mu S_{\text {oed. }} \\
\text { ここ, } \mu=A+C(1-A)
\end{gathered}
$$

$A:$ 間げき水圧倸数

$$
C=\frac{\int_{0}^{z} \Delta \sigma_{3} d z}{\int_{0}^{z} \Delta \sigma_{1} d z}
$$

Lambe $^{10)}$ は Skempton-Bjerrum にならって, 沈下 量がせん断変形による瞬時沈下 $S_{i}$ と異方性圧力下での 圧密沈下 $S_{c}$ との和であり, また, 沈下量 $S_{T F}$ は圧縮 危受ける層の厚さと鉛直ひずみとの積に等しいとして
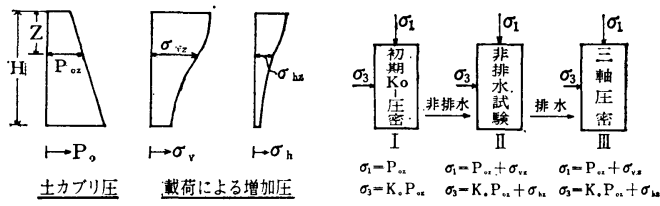

図-2

$S_{T F}=\sum \delta h_{0}\left(\epsilon_{1 i}+\epsilon_{1 c}\right)$

ここに, $\delta h_{0}$ : 圧縮される層の厚さ

$\epsilon_{1 i}:$ 非排水状態での鉛直ひずみ

$\epsilon_{1 c}:$ 圧密による鉛直ひずみ

を導びき, 有効応力軌跡を使って $\epsilon_{1 i}, \epsilon_{1 c}$ を定める方法 を見いだした。ただし，圧密中の側方拘束圧の変化が未 知量としてあるから, 明確汇有効応力軌跡を定めること ができないとしている。

また，Davis，Poulos ${ }^{11}$ は 図一2 に示すように三軸試 験によって非排水試験と圧密試験とを行ない

$$
S_{T F}=\Sigma \frac{1}{E^{\prime}}\left(\sigma_{z}-\nu^{\prime} \sigma_{x}-\nu^{\prime} \sigma_{y}\right) \delta h_{0}
$$

ここに, $E^{\prime}, \nu^{\prime}$ は対応する異方性応力の下でのひずみ $\left(\epsilon_{i}+\epsilon_{c}\right)$ から定められる土の骨格が示すパラメーター によって算出するとした。図において明らかなように， 側方拘束圧が圧密中，一定に保たれており，したがって 側方収縮が生ずることになる。このことは現実の問題と 照して矛盾するもので，むしろ圧密中に，側方変形が生 じないよう圧密とともに側方拘束圧が減少すると考える 方がより合理的と思われる。

\section{3. サンドドレーンによる $K_{0}$-圧密の修正理論}

図一3 に示すように, サンドドレーンを含む円筒状供 試体に時間に無関係に一定の鉛直圧力を載荷し， $K_{0}$-状 態 (側方変形零) で圧密する。この条件を満足するため には側方拘束圧 $P_{c}$ が圧密の進行とともに減少する。し たがって，図のように，時間とともに減少する等方性圧
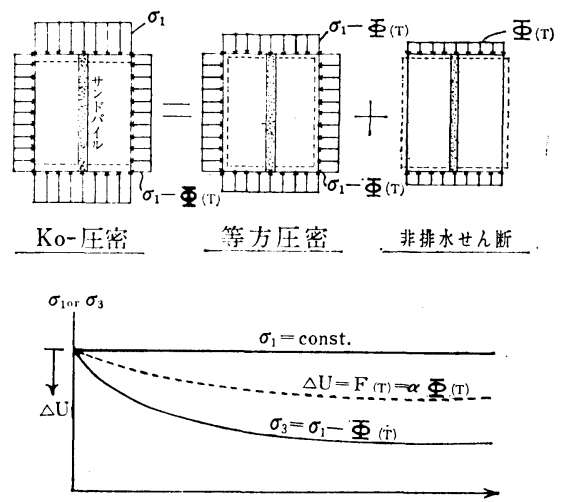

図一3 
カによる圧密と, 逆に増大する主忘力差による形状変形 とを受け，側方変形零を維持する。

このように，時間とともに荷重が変動する場合に対す る圧密基本式は

$$
\frac{\partial u}{\partial t}=C_{v h}\left(\frac{1}{r} \frac{\partial u}{\partial r}+\frac{\partial^{2} u}{\partial r^{2}}\right)+f_{(r, t)}
$$

ここに, $f_{(r, t)}$ : 任意時間の荷重変化によって起こる 間げき水圧の変化率

図に示すように，ある時間の間げき水圧の変化量 $\left(\Delta u_{T}\right)$ を $F_{(T)}$, 拘束圧力の変化量 $\left(\Delta \sigma_{3}\right)$ を $\left.-\Phi_{(T)}\right)$ と置 くと, 鉛直圧力の変化量 $\left(\Delta \sigma_{1}\right)$ は零であるから, $\left(\Delta \sigma_{1}\right.$ $\left.-\Delta \sigma_{3}\right)=\Phi_{(T)}$ となり

$$
F_{(T)}=-(1-A) \Phi_{(T)}=\alpha \Phi_{(T)}
$$

\section{ここに, $A:$ Skempton $^{12)}$ の間げき水圧係数}

$$
\alpha:-(1-A) \text { (負号は減少を表わす) }
$$

なる関係が成り立つ。

式 $(20)$ を, $f_{(r, t)}$ は $r$ に無関係に一定とし, 境界条 件

$$
\left.u\right|_{r=r_{w}}=\left.0 \quad \frac{\partial u}{\partial r}\right|_{r=r_{e}}=0
$$

初期条件,

$$
\left.u\right|_{t=0}=\left.P \quad \frac{\partial u}{\partial t}\right|_{t=0}=0
$$

のもとに解くと，

$$
\begin{aligned}
u= & 2 u_{0} \sum_{\xi} A_{\xi}\left[J_{0}\left(\frac{\xi}{r_{w}} r\right)-\frac{J_{1}(n \xi)}{Y_{1}(n \xi)} Y_{0}\left(\frac{\xi}{r_{w}} r\right)\right] \\
& \cdot \exp \left(-4 n^{2} \xi^{2} T\right)-2 \sum_{\xi} A_{\xi}\left[J_{0}\left(\frac{\xi}{r_{w}} r\right)\right. \\
& \left.-\frac{J_{1}(n \xi)}{Y_{1}(n \xi)} Y_{0}\left(\frac{\xi}{r_{w}} r\right)\right] \int_{0}^{T} f_{(\tau)} \epsilon^{-4 n^{2} \xi^{2}(T-\tau)} d \tau
\end{aligned}
$$

となる。したがって，ある時間の圧密による体積変化量 $\Delta V_{(T)}$ は $u_{0}=P$ と置いて

$$
\begin{aligned}
\Delta V_{(T)} & =2 \pi h m_{v} \int_{r_{w}}^{r_{e}}\left\{\left(P-\alpha \Phi_{(T)}\right)\right. \\
& -\left(2 P \sum _ { \xi } A _ { \xi } \left[J_{0}\left(\frac{\xi}{r_{\omega}} r\right)\right.\right. \\
& \left.-\frac{J_{1}(n \xi)}{Y_{1}\left(r_{1} \xi\right)} Y_{0}\left(\frac{\xi}{r_{w}} r\right)\right] \epsilon^{-4 n^{2} \xi^{2} T} \\
& -2 \sum_{\xi} A_{\xi}\left[J_{0}\left(\frac{\xi}{r_{w}} r\right)-\frac{J_{1}(n \xi)}{Y_{1}(n \xi)}\right. \\
& \left.\left.\cdot Y_{0}\left(\frac{\xi}{r_{w}} r\right)\right] \int_{0}^{T} f_{(\tau)} \epsilon^{-4 n^{2} \xi^{2}(T-\tau)} d \tau\right\} r d r \\
= & m_{v} V P\left\{1+4 \sum_{\xi} B_{\xi} \epsilon^{-4 n^{2} \xi^{2} T}\right. \\
& \left.-\left(\alpha \Phi_{(T)}+4 \sum_{\xi} B_{\xi} \int_{0}^{T} f_{(\tau)} \epsilon^{-4 n^{2} \xi^{2}(T-\tau)} d \tau\right)\right\}
\end{aligned}
$$

ここに, $V=2 \pi h \int_{r_{w}}^{r_{e}} r d r=\pi\left(r_{e}^{2}-r_{w}^{2}\right) h$

$$
B_{\xi}=\frac{V_{1}{ }^{2}(\xi)}{\xi^{2}\left(n^{2}-1\right)\left\{V_{1}^{2}(\xi)-n^{2} V_{0}^{2}(n \xi)\right\}}
$$

これより，ある時間の平均体積ひずみ $\varepsilon_{\mathrm{ave}}$ は

$$
\varepsilon_{\mathrm{ave}}=\frac{\Delta V}{V}
$$

で半径方向の収縮ひずみ $\epsilon_{r}$ は

$$
\epsilon_{r}=\frac{1}{m} \varepsilon_{\mathrm{ave}}
$$

とする。一方，その時間においては $\Phi_{(T)}$ の主応力差を 受け，せん断変形による半径方向の膨張ひずみ $\epsilon_{r}{ }^{\prime}$ は

$$
\epsilon_{r}{ }^{\prime}=-\frac{\nu}{E} \Phi_{(T)}
$$

となる。側方変形が零となるためには式 (25), (26) の和 が零でなければならない。この条件によって

$$
\begin{aligned}
& \Phi_{(T)}=\beta P\left\{1+4 \sum_{\xi} B_{\xi} \epsilon^{-4 n^{2} \xi^{2} T}-\frac{4}{P} \sum_{\xi} B_{\xi}\right. \\
& \text { - } \left.\int_{0}^{T} f_{(\tau)} \epsilon^{-4 n^{2} \xi^{2}(T-\tau)} d \tau\right\}
\end{aligned}
$$

$$
\text { ここに } \beta=\frac{3 / m(1-2 \nu)}{\nu+3 / m(1-2 \nu) \bar{\alpha}}
$$$$
\text { したがって，式 (23),(27)より }
$$

$$
\begin{aligned}
\Delta V_{(T)}= & (1-\alpha \beta) P m_{v} V\left[1+4 \sum_{\xi} B_{\xi} \epsilon^{-4 n^{2} \xi^{2} T}\right. \\
& \left.-\frac{4}{P} \sum_{\xi} B_{\xi} \int_{0}^{T} f_{(\tau)} \epsilon^{-4 n^{2} \xi^{2}(T-\tau)} d \tau\right]
\end{aligned}
$$

を得る。また,式 (21) によって間げき水圧の時間変化は $\alpha \Phi_{(T)}$ であるから, その変化率 $f_{(\tau)}$ は時間で微分して,

$$
\begin{aligned}
f_{(\tau)}= & \frac{d F_{(T)}}{d T}=-16 n^{2} \alpha \beta P\left\{\sum_{\xi} \xi^{2} B_{\xi} \epsilon^{-4 n^{2} \xi^{2} T}\right. \\
& \left.+\frac{1}{P} \sum_{\xi} \xi^{2} B_{\xi} \int_{0}^{T} f_{(\tau)} \epsilon^{-4 n^{2} \xi^{2}(T-\tau)} d \tau\right\}
\end{aligned}
$$

を得る。ラプラス変換によってこの式を解くと

$$
\begin{aligned}
& f_{(\tau)}=-P\left[\sum \theta_{i} \exp \left(-M_{i} T\right)\right. \\
&+\sum_{i=1}^{\infty} \sum_{j=1}^{n} \frac{\theta_{i} S_{\lambda_{i}}}{\lambda_{j}+M_{i}}\left(\epsilon^{-M_{i} T}-\epsilon^{\lambda_{j} T}\right) \cdots \cdots \\
& こ こ に, \quad \theta_{i}=\frac{16 \alpha \beta n^{2} V_{1}\left(\xi_{i}\right)}{\left(n^{2}-1\right)\left[V_{1}^{2}\left(\xi_{i}\right)-n^{2} V_{0}^{2}\left(n \xi_{i}\right)\right]} \\
& M_{i}=4 n^{2} \xi_{i}{ }^{2} \\
& \lambda_{j} \text { は特性方程式 } \\
& \frac{\theta_{1}}{\lambda+M_{1}}+\frac{\theta_{2}}{\lambda+M_{2}}+\cdots+\frac{\theta_{n}}{\lambda+M_{n}}-1=0
\end{aligned}
$$

の根である。

$$
S_{\left(\lambda_{j}\right)}=\frac{\left(\lambda_{j}-M_{1}\right)\left(\lambda_{i}-M_{2}\right) \cdots\left(\lambda_{j}-M_{n}\right)}{\left(\lambda_{j}+\lambda_{1}\right) \cdots\left(\lambda_{j}-\lambda_{j-1}\right)\left(\lambda_{j}-\lambda_{j+1}\right) \cdots\left(\lambda_{j}-\lambda_{n}\right)}
$$

式 (27), (28) のかっこ内を压密度 $U_{(\tau)}$ で定義すると，

$$
U_{(\tau)}=1+4 \sum_{\xi} B_{\xi} \epsilon^{-4 n^{2} \xi^{2} T}-\psi(\tau)
$$



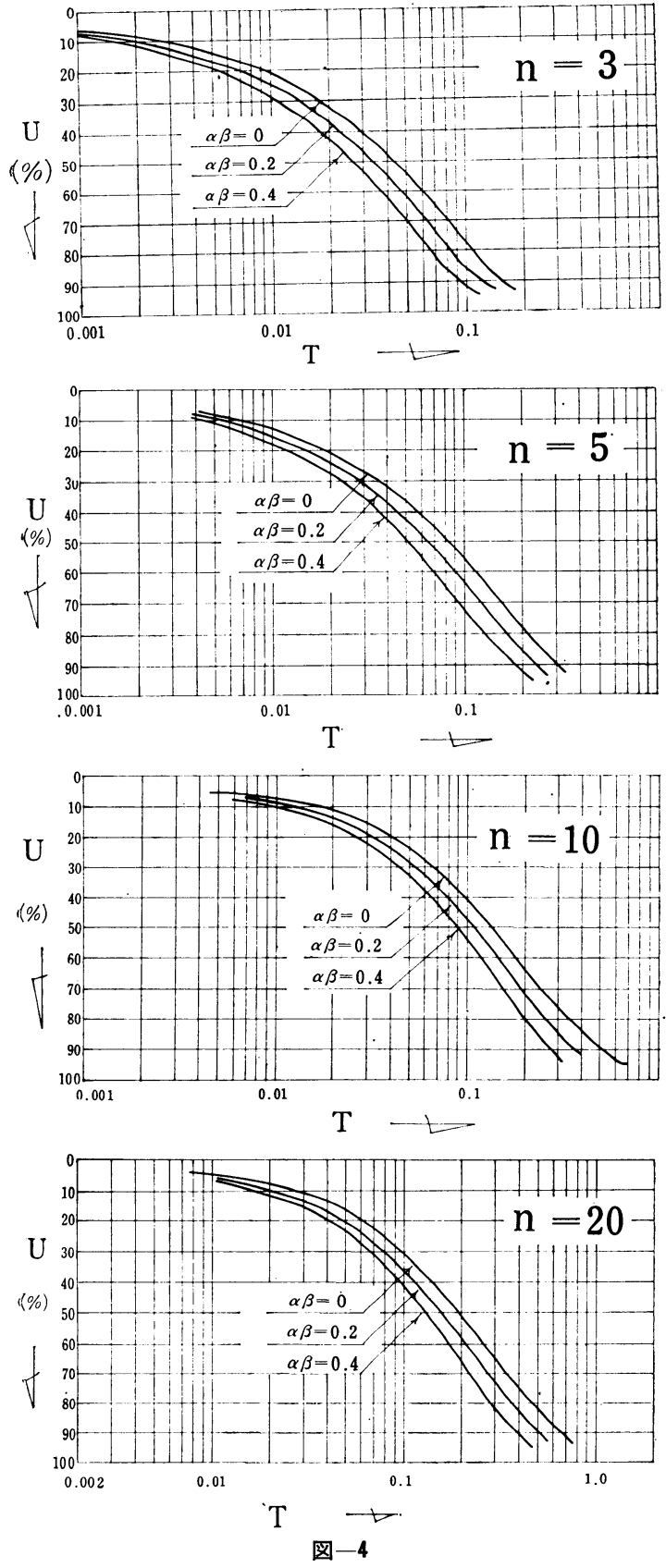

ここに $\psi(\tau)=\frac{4}{P} \sum_{\xi} B_{\xi} \int_{0}^{T} f_{(\tau)} \epsilon^{-4 n^{2} \xi^{2}(T-\tau)} d \tau$

となり, $f_{(\tau)}$ は式 $(30)$ にょって定まっているから $U_{(T)}$ を算定することができる。

$n$ が 3,5,10,20の 4 種について, それぞれパラメータ 一 ( $\alpha \beta$ 值) $0.2,0.4$ として計算し, その結果を図一 4 に示した。な抢， $\alpha \beta=0$ の曲線は従来の free strain による理論值を示す。

これらの曲線の中から対応するものを選び

$$
\begin{aligned}
& \Delta V_{(T)}=(1-\alpha \beta) P m_{v} V U_{(T)} \\
& \Delta P_{c(T)}=\Phi_{(T)}=\beta P U_{(T)} \cdots \cdots
\end{aligned}
$$

によって，ある時間の体積変化量， $\Delta V_{(T)}$ と側方拘束 圧力の変化量 $\Delta P_{c(T)}$ とを算定することができる。

\section{4. 実験}

\section{(1) 実験とその目的}

まず，検照のために行なった実験を項目別にまとめる と表一1 の上うになる。

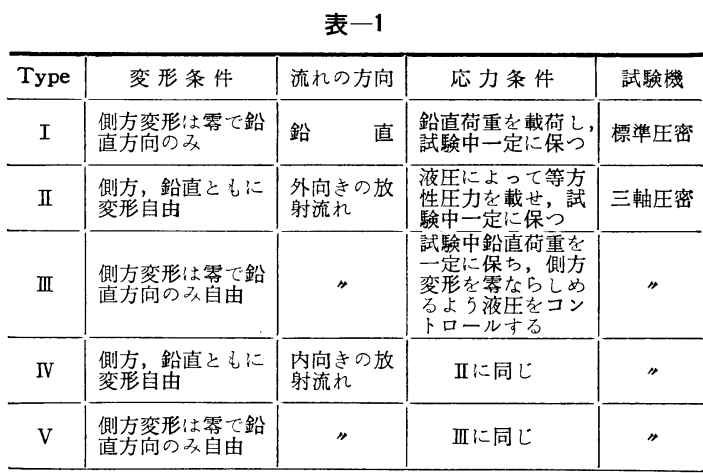

Type I は, 一般に行なわれている標準圧密で側方拘 束状態で鉛直方向のみに流れを起こさせて圧密する。

Type II V は,図一5 のように液体を封じ込んだ可泋 性の上部加圧板を持つ特殊三軸圧密試験機を使用し, 水 平方向に放射流れを起こさせて圧密する。このうち Type II , III は円筒形供試体の周面にはりつけた滤紙に向かっ て外向きの流れを起こさせるのに対して, Type IV, V は円筒形供試体の中央に鉛直にせん孔して，標準砂（粒 径 $0.105 \mathrm{~mm}$ 以上のもののみを使用)を充填し,サンドド レーン模型を形成して内向きの流れによって圧密する。

Type II , IV は等方性圧力のもとで, 鉛直, 側方とも に変形自由とし, Type III, V は一般に $K_{0}$-試験といわ れている試験法，すなわち，試験中のすべての時間にお いて側方変形が需となるよう，側方拘束圧力をコントロ ールして圧密を起こさせる。

次に実験の目的は
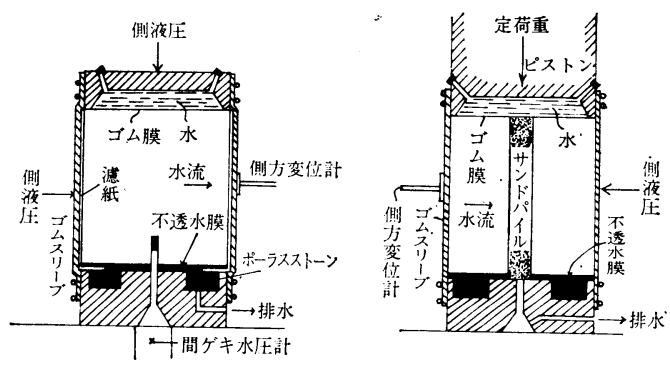

図-5 
a）従来の圧密理論は等方性圧力のもとで変形があら ゆる方向に自由である場合において成立する。実際に， 地盤中で土が圧密を受ける場合, 側方変形が抑制され, どちらかというと $K_{0}-$ 状態に近い条件での圧密を考えね ばならない。したがって，先述のように，時間とともに 圧力変化を伴う場合の修正理論を適用すべきであろら。 そこで, 従来理論と Type II, IV の実験を, 修正理論と Type III, V の実験結果とを対応させて検照する。

b) 等方圧密と $K_{0}$-圧密との比較試験を行ない， $K_{0}$ 圧密理論のパラメーター $(\alpha \beta$ 值 $)$ を定めて, $K_{0}$-圧密の 解析を行なう。

c） サンドドレーンのように, 内向きの放射流れを起 こさせる場合と，外向きの放射流れを起こさせる場合と で圧密諸倸数で変動するかどらかを調べる。

d）標淮圧密と $K_{0}$-状態での放射流れによる圧密との 比較を行なう。このことは, サンドドレーンの設計に際



（a）外向きの流れ(等方圧密)

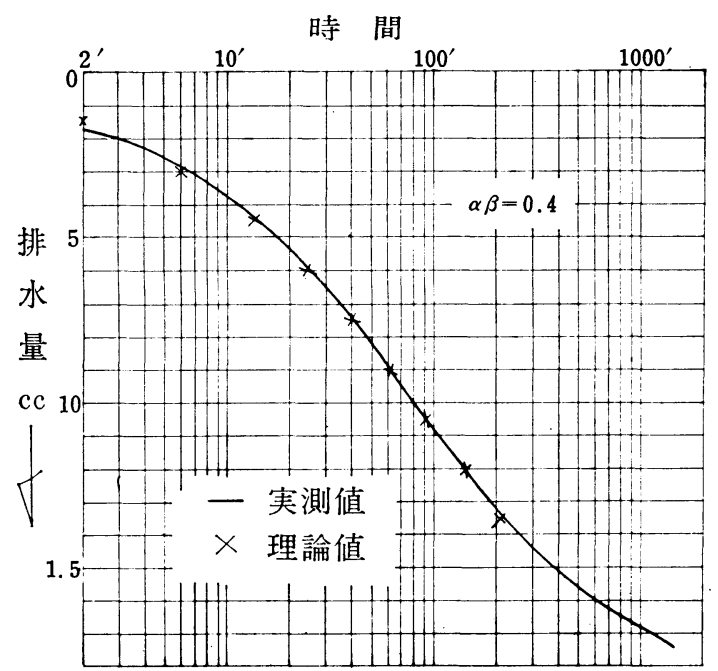

(b) 外向きの流れ (Ko-圧密)
して，標準圧密試験結果を使用することの可否を検討す ることになる。

e）鉛直方向の透水係数と水平方向のそれとの比較を 行なう。

以上の目的に沿うょう，同一試料を使って比較試験を 行なった。

\section{（2）実験結果と考察}

理論々試験結果の対応は圧密度一時間曲線 $(U-T$ 曲 線) と試験で実測された体積変化 (排水量)一時間曲線と の合致の良し悪しで判断することができる。

実験結果の一例を以下にあげる。

図一6(a) は Type II の試験結果で従来理論の $U-T$ 関係 ${ }^{3)}$, 図一6 (b) は Type III の試験結果で $K_{0}$-状態 の修正理論による $U-T$ 関倸 ${ }^{1}$, 図一6 (c) は Type IV の試験結果で free strain による従来のサンドドレーン 理論による $U-T$ 関倸 ${ }^{14)}$, 図一6(d)は Type V の試験 結果でここに示した修正理論式 (32) による $U-T$ 関倸

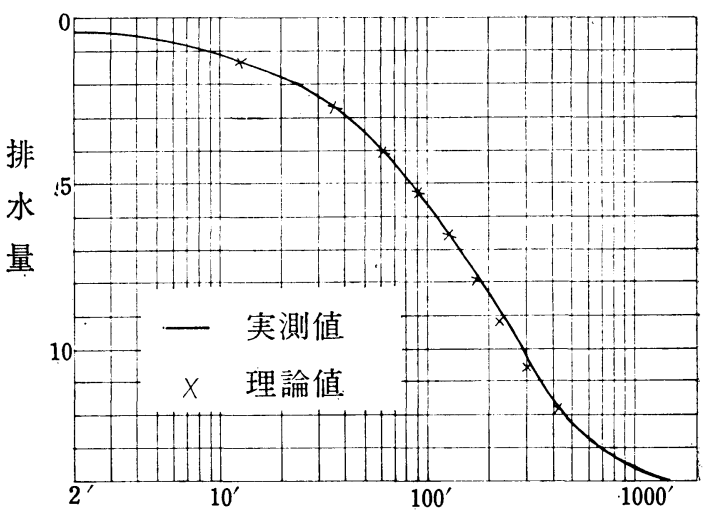

時 間—

(c) 内向きの流机(等方圧密 $\mathrm{n}=9$ )

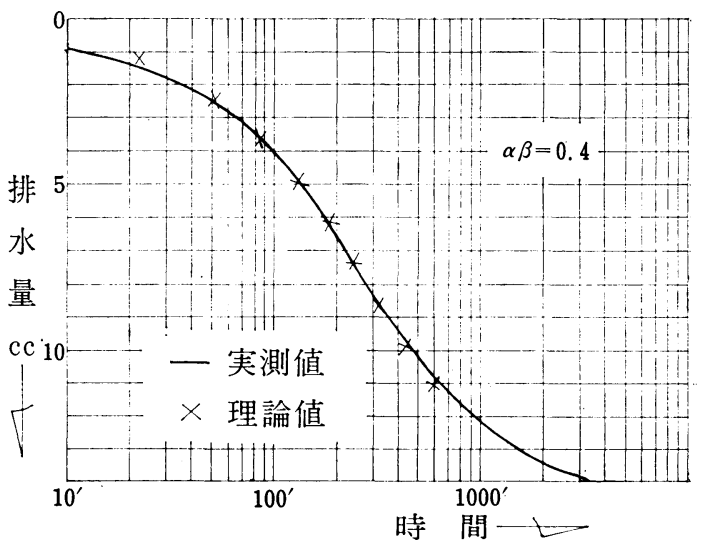

（d）内向きの流れ $\left(\mathrm{K}_{0}-\right.$ 圧密 $\left.\mathrm{n}=10\right)$ 


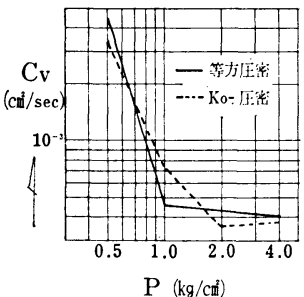

(a) 外向きの流れ

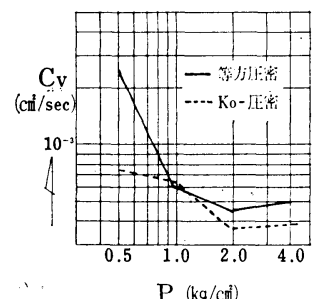

(b)内向きの流れ
図一7
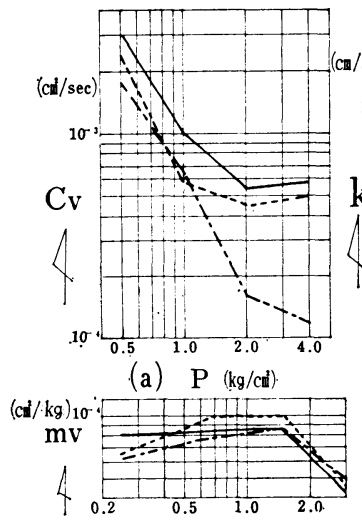

(b) $\overline{\mathrm{P}}(\mathrm{kg} / \mathrm{cm})$ (a) $\mathrm{P}(\mathrm{kg} / \mathrm{cil})$

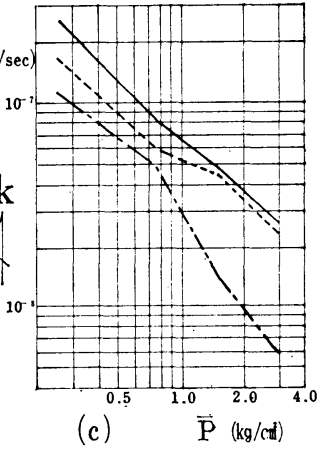

外向きの流れ 内向きの流れ 標 準 圧 密
图一8

（図一4）によって，それぞれ計算され，それらの理論値 を試験曲線に対比させてプロットした。これらの図で明 白なように，いずれも理論值と実測值とが良く合致して おり, 対応理論の採択の妥当性が証明される。なお, Type III, V の試験結果と理論值との若干のずれは, 側 方圧力をコントロールする際の操作上のずれに基因する ものと思われる。

図一7は同一試料について行なった等方圧密（従来理 論) と $K_{0}$-圧密 (修正理論) についての比較試験結果 で（a）は外向きの流れ，(b) は内向きの流れ（サンドド レーン）に対するものを示す。いずれも両者が良く合致 していることから， $K_{0}$-圧密の設計に際して等方圧密試 験結果を代用し得ることを示す。

図一8 は放射流れの方向による圧密諸係数の変動の有 無をチェックしたものである。すなわち，同一の試料に ついて, Type II と Type IV の試験を行なって, それ ぞれを対比させた。なお，ドレーン用材として，Type II は濾紙 $\left(k_{p}=10^{-5} \mathrm{~cm} / \mathrm{sec}\right)$, Type V は選別された標 準砂 $\left(k_{s} \fallingdotseq 10^{-2} \mathrm{~cm} / \mathrm{sec}\right)$ と透水係数の極端に相違するも のを使っていること，境界条件が違らことで両者間のド レーンの損失水頭による圧密時間のずれが生ずる。そこ で, Type II については Bishop, Gibson ${ }^{15}$, Type IV については網干・吉国 ${ }^{16)}$ の解に従って補正した。このよ
うにして両者を比較すると，圧密諸係数は流れの向きに 支配されることはないといえるようである。

また，図一8 は，鉛直流れ（標準圧密）と放射流れと による圧密諸係数の対比をも行なっているが，図より明 らかなように体積圧縮係数 $m_{v}$ (b図) は三者において 差異がないが, 圧密係数 $C_{v}$ (a 図) と透水係数 $k(\mathrm{c}$ 図) とは流れの方向が水平と鉛直とでかなりくい違う。これ は土の生成過程において生ずる異方性の点から，すでに 推定されていたことである。以上を総括すると，

(i) 等方圧密(変形があらゆる方向に自由)について は従来理論， $K_{0}$-圧密については修正理論が適応する。

(ii）放射流れの向き（内向きか，外向きか）によっ て圧密諸係数が支配されることはないようである。

(iii) $K_{0}$-圧密のサンドドレーンの設計に際して，等 方圧密の外向きの流れ (Type II) による試験で得られ る $C_{v}$ 值を採用することができる。このことは, どこの 試験室にもある三軸圧縮試験機を利用して，試験するこ とができることを意味している。ただし，現段階では $K_{0}$-圧密理論の使用に際して必要なパラメーター $(\alpha \beta$ 值 $)$ は，先に ${ }^{11}$ 述べたように $K_{0}$ 一圧密と等方圧密試験との比 較において算定しなければならない。

（iv） 体積圧縮係数 $m_{v}$ は流れが鉛直か，放射である かによって変化することはないようである。いい換える と, 沈下量の算定にあっては標準圧密試験による $m_{v}$ 值 を採用することができる。

（v）圧密係数 $C_{v}$, 透水係数 $k$ については流れの方 向（鉛直か，放射か）に支配される。したがって，サン ドドレーンの設計に使用される压密倸数 $C_{v}$ については 放射流れ（外向き）による試験值を使用しなければなら ない。

\section{5.あとがき}

筆者は数年来, サンドドレーンが打設された地盤の圧 密が，その層の中央付近では放射流れのみによって起こ されると考え，この問題を取り扱ってきた。そして，従 来の圧密理論が，変形条件を全く無視したものであり， 現実の問題と照合して, 当然, 理論の修正が必要であろ うことを指摘した。

従来のサンドドレーンによる圧密理論は，“変形が鉛 直，水平ともに自由”なる条件においてのみ適合する。

自然地盤中において生ずる圧密は，水平方向の変形が 抑制されるため，側方拘束圧の緩和を伴って，圧密変形 と形状変形とが混在する形で鉛直方向に圧縮されると思 われる。このような考え方は，沈下量算定の修正理論で Lambeによって取り入れられ，圧密理論に関しては， 赤井ら ${ }^{17)}$ が最初であった。 
実験において確認したように, 沈下量算定の重要なパ ラメーターである $m_{v}$ が, 明確に相違する変形条件のも とで，その絶対值がさほど影響されないことがわかっ た。このことを逆に考えると, 沈下量の算定值が算定法 およびその試験法に若干のくい違いがあっても, さほど 大きな誤差とはなり得ないと思われる。

しかし, 圧密時間にあっては, 等方圧密 (従来理論) と $K_{0}$-圧密との間には非常に大きな開きがある。もち万 ん, 現段階では，地盤中の圧密が完全な $K_{0}$-状態で起こ るとはいえないから, その誤差がそのまま, 現実の問題 の誤差となるとはかぎらないが, 誤差の大きな要因とな り得ることは確実であろら。

\section{参考文 献}

1）中野 : 放射流れを受ける側方拘束圧密の理論, 土木学会 論文報告集, No. 192, pp. 91-98 (1971).

2) Rendulic: Der hydrodynamische Spannungsausgleich in zentral entwässerten Tonzylindern, Wasserwirtschaft und Technik (1935).

3) 三笠 : 軟弱粘土の圧密 (1963).

4) Carrilo: Simple Two and Three Dimensional Cases in the Theory of Consolidation of Soil, J. Math. Physics Vol. 21 (1942).

5) Barron : Consolidation of Fine-Grained Soil by Drain Wells, Trans. A.S.C.E. (1947).

6）矢内・水野：サンドドレーンの圧密理論について，土木 学会論文集, No. 36 (1956).
7) Leeuw : The Theory of Three-dimensional Consolidation Applied to Cylindrical Bodies", Proc. 6 th int Conf. S.M.F.E. (1965).

8) Biot: General Theory of Three-Dimensional Consolidation, J. Appl. Phys. 12 (1941).

9) Skempton, Bierrum : A Contribution to the Settlement Analysis of Foundations on Clay, Geotechnique 7 (1957).

10) Lambe : Method of Estimating Settlement", Proc. of A.S.C.E. Vol. 90 SM.5 (1964).

11) Davis, Poulos : The Use of Elastic Theory for Settlment Prediction under Three-Dimensional Conditions, Geotechnique 18 (1968).

12) Skempton: "The Pore-Pressure Coefficients A and B, Geotechnique 4 (1954).

13）中野: 軟弱粘土用三軸圧密試験機の試作について, 土と 基礎, Vol. 8, No. 3 (1960).

14）土質工学会編：土質工学ハンドブック, p. 160 .

15) Bishop, Gibson : The Influence of the Provisions for Boundary Drainage on Strength and Consolidation Characteristics of Soil Measured in the Triaxial Apparatus, Laboratory Shear Testing of Soil A.S.T.M. (1963).

16) Aboshi, Yoshikuni : A Study on the Consolidation Process Affected by Well Resistance in the Vertical Drain Method, Soil and Foundation, Vol. VII No. 4 (1967).

17）赤井・足立 : 有効応力より見た飽和粘土の一次元圧密と 強度特性に関する研究, 土木学会論文集, No. 113 (1965).

(1971.5.21 · 受付) 